2. To: (Receiving organization)

300 Area Liquid Effluent Engineering

5. Proj./Prog./Dept./0iv.:

$\mathrm{L}-070$

8. Originator Remarks:

This document provides the final report for the acceptance testing of mechanical equipment and instrumentation for the L-070 Project.

Key Words: L-070, ATR, Acceptance Test Report, 3906, Lift Station, 350-A, 300 Area Process Sewer.

11. Receiver Remarks:

None
3. From: (Originating organization) 300 Area Liquid Effluent Engineering

6. Cog. Engr.:

C. M. Lol1
4. Related EDI No.

$N / A$

7. Purchase order No.: $\mathrm{N} / \mathrm{A}$

9. Equip./Component No.: $N / A$

10. System/Btdg./Facility:

300 Area Process Sewer

12. Major Assm. Dwg. No.:

N/A

13. Permit/Permit Application No.: N/A

14. Required Response Date: $N / A$

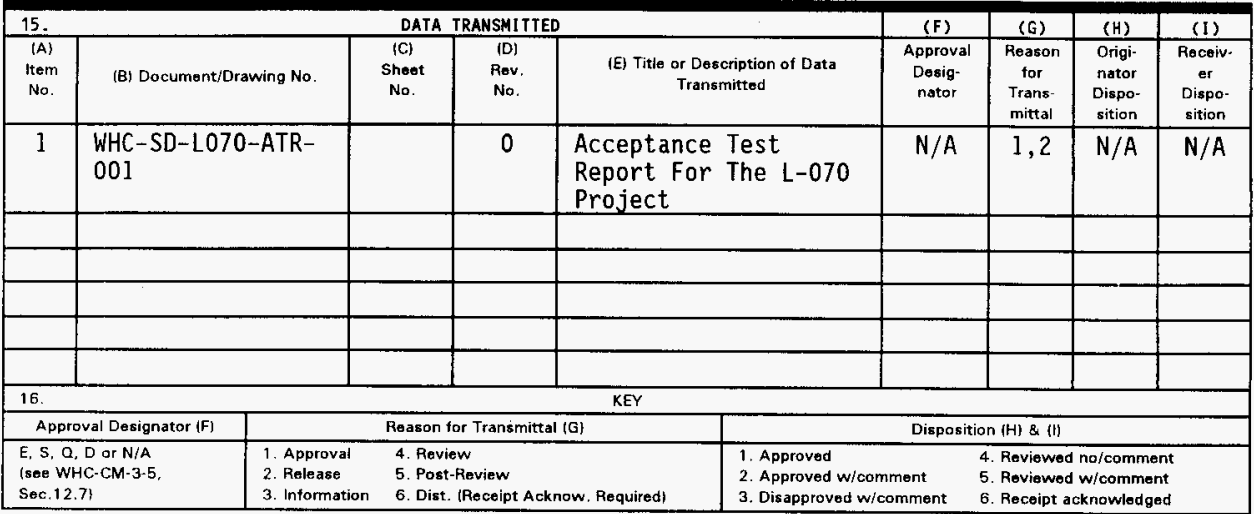

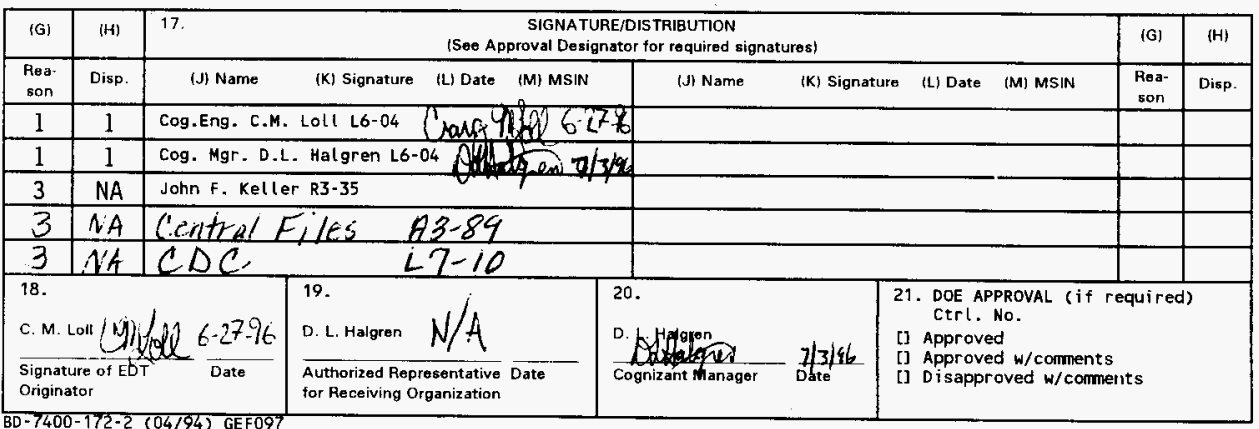




\title{
Acceptance Test Report For The L-070 Project
}

\author{
C.M. Loll
}

Westinghouse Hanford Company, Richland, WA 99352

U.S. Department of Energy Contract DE-AC06-87RL10930

$\begin{array}{ll}\text { EDT }: 601873 & \text { UC: } 506 \\ \text { Org Code: } 86730 & \text { Charge Code: } \\ \text { B\&R Code: } 39 \text { EW70302 } & \text { Total Pages: } 22\end{array}$

Key Words: 3906, 350-A, lift station, L-070 Project, 300 Area, process sewer, acceptance test procedure, ATP, acceptance test report, ATR

Abstract: This document contains the acceptance test report for the mechanical equipment and instrumentation installed per the L-070 Project. The systems that were tested were the pump controls for the 3906 Lift Station and the 350-A Lift Station. The verification of an alarm signal installed between the 3906 lift station and the 340 Facility (3707F Bldg.) was also performed.

TRADEMARK DISCLAIMER. Reference herein to any specific comercial product, process, or service by trade name, trademark, manufacturer, or otherwise, does not necessarily constitute or imply its endorsement, recormendation, or favoring by the United States Government or any agency thereof or its contractors or subcontractors.

Printed in the United states of America. To obtain copies of this document, contact: WHC/BCS Document Control Services, P.O. Box 1970, Mailstop H6-08, Richland WA 99352, Phone (509) 372-2420, Fax (509) 376-4989.
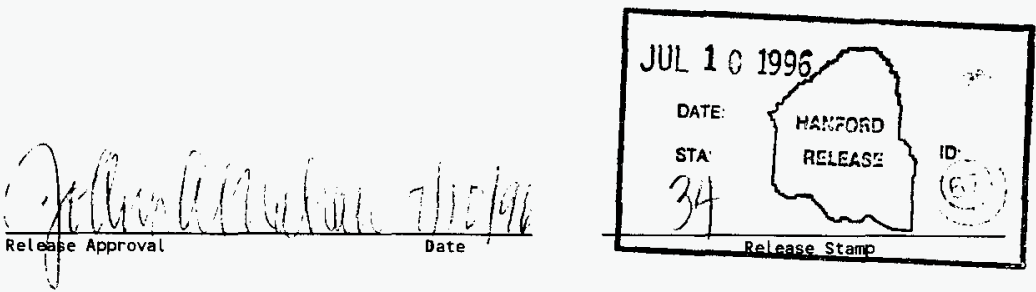

Approved for Public Release 


\section{SUMMARY}

ACCEPTANCE TEST PROCEDURE FOR THE L-OTO PROJECT MECHANICAL EQUIPMENT AND INSTRUMENTATION, WHC-SD-L070-ATP-001, REV. 0 , has been completed and is documented in this acceptance test report. All exceptions have either been accepted or transferred to the construction punchlist where they will be tracked to their completion. This summary identifies and explains changes and exceptions to the acceptance test procedure.

0 The lift stations (3906 and 350-A) were not ready to be tested at the same time so they were signed off, ready-to-test, separately in section 4.1.

o The testing which was performed in the ATP was within the scope of the applicable pre-job safety analyses for power installation at both 1 ift stations (this work was being performed the same day, just prior to testing, at both lift stations). The prerequisite for signing off on a pre-job roster was changed to having signed off on the pr-job saftey analysis roster. The Job Safety Analyses and the signed off rosters are included as part of the ATR.

There were several exceptions/changes listed in the Exception/Change Log.

- Section 6.0, step 6.8, required the verification of a local readout on the 3906 Lift Station flowmeter, FIT-3906. This flowmeter was not working properly and did not register any flow during test performance. The correct operation of the flowmeter was included as a construction punchlist item. The flowmeter vendor came on site on 6/24/96. He determined that the flow transmitter was missing some components. He removed the transmitter and shipped it back to the factory. It will be shipped back to the vendor and he will return to the site in order to reinstall and program it.

- Section 6.0, step 6.9 (and step 8.7 for $350-A$ ), tests the lead/lag switch ability between the sump pumps. This was supposed to be accomplished by switching the Hand/Off/Auto switch for the lead pump from Auto to off and then back to Auto. This is not the way the lead/lag status works. The lead lag status on the 3906 and 350-A lift station pumps only switches when the sump has been pumped down and the low level shutoff switch is reached. Upon making the appropriate change to step 6.9 , the lead/lag status switched appropropriately.

- The alarm light was not working at the 3906 lift station when the ATP was performed, however, it was fixed within two days of the completion of the testing.

- During testing the hi hi level alarm at the 3906 lift station was not hooked up to be received at the 340 computer. This item was listed in the exceptions/change log and placed on the construction punchlist.

The hi hi level alarm circuit has since been completed and the testing was performed to close out the punchlist item. 
WHC-SD-L070-ATR-001, REV. 0

ACCEPTANCE TEST REPORT FOR THE

L-070 PROJECT

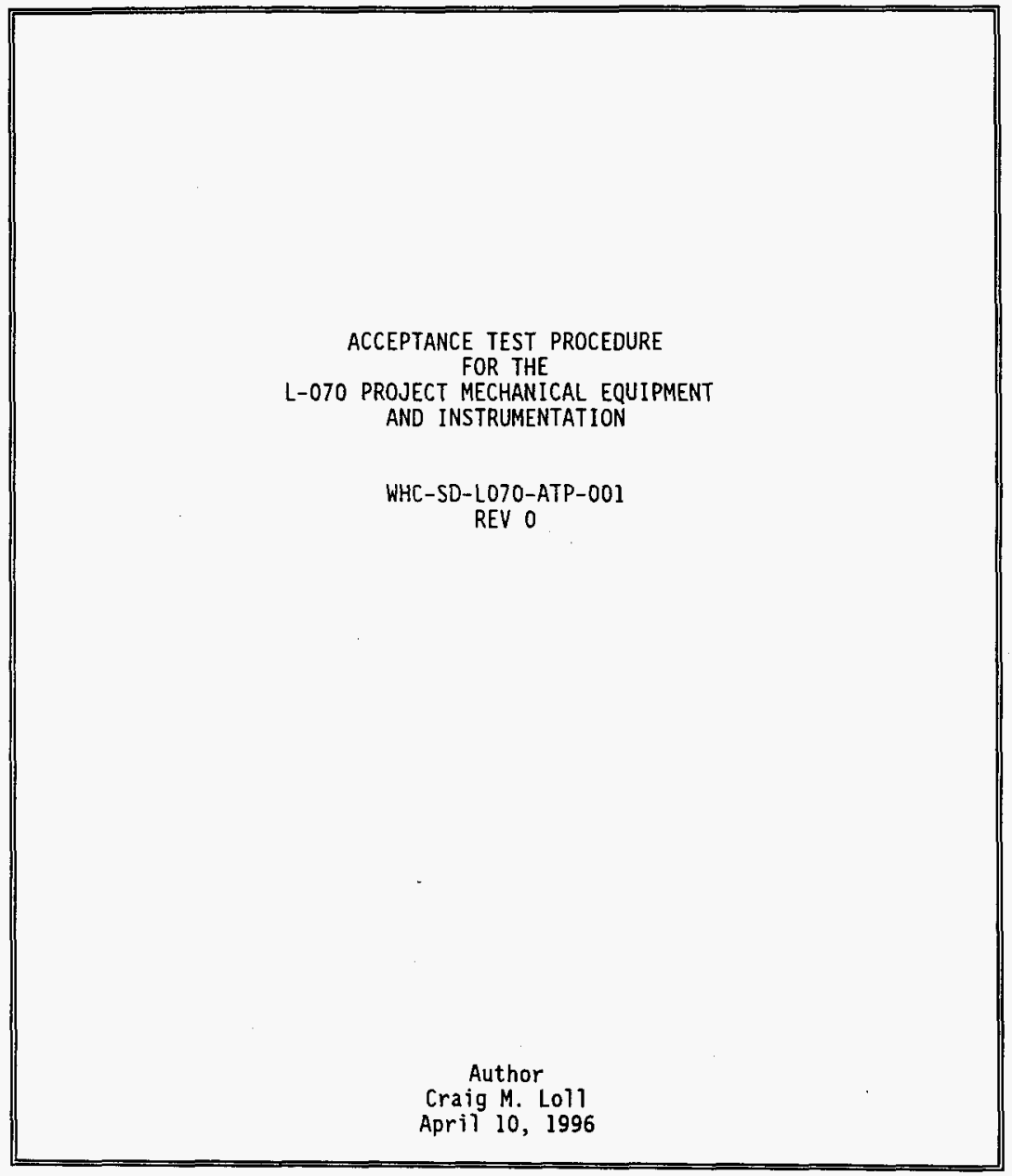


WHC-SD-L070-ATR-001, REV. 0

ACCEPTANCE TEST REPORT FOR THE L-070 PROJECT

TABLE OF CONTENTS

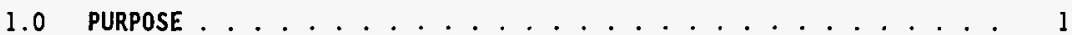

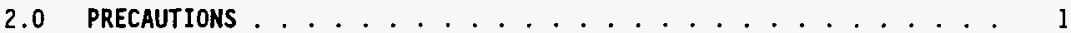

3.0 ADMINISTRATION AND AUTHORITY . . . . . . . . . . . 2

4.0 PREREQUISITES . . . . . . . . . . . . . . . . . 4

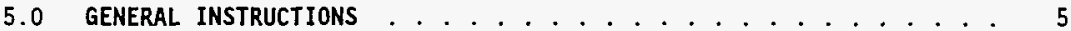

6.0 LIFT STATION 3906 PUMP $(L S P-1,2)$ TESTING $\ldots \ldots \ldots$

7.0 MANHOLE PS-72 SIGNAL ................ 8

8.0 LIFT STATION $350-A$ PUMP $(L S P-1,2)$ TESTING $\ldots \ldots \ldots$ Appendix A: Instructions for completing Exceptions Log ....... 11 AppendiX B: ATP EXCEPTIONS/CHANGES . . . . . . . . . . . 12 
WHC-SD-L070-ATR-001, REV. 0

ACCEPTANCE TEST REPORT FOR THE

L-0TO PROJECT

\subsection{PURPOSE}

The purpose of the L-070 Project Acceptance Test Procedure is to verify the the proper functioning of 300 Area Process Sewer and Retention Process Sewer equipment required to be installed per L-070Cl, Construction Specification, 300 Area Process Sewer Upgrade.

Specifically, this ATP addresses the functionality of the $3906 \mathrm{Lift}$ Station, 350-A Lift Station, and the receipt of the PS Manhole \#72

flow signal at 300 Area TEDF.

\subsection{PRECAUTIONS}

\subsection{PERSONNEL SAFETY}

2.1.1 Manholes at the lift stations will need to be open in order to add water for testing. Anchored railings, or a means of keeping personnel at least six feet back from the opening will be present around manholes while they are open.

2.1.2 Work will be performed under the safety rules and information contained in the existing job safety analyses (JSA's) for construction activities.

2.1.3 All personnel performing ATP related work sha1] read and sign the USA prior to the commencement of testing. The Test Engineer shall be responsible for ensuring that this requirment is met. 
WHC-SD-L070-ATR-001, REV, 0

ACCEPTANCE TEST REPORT FOR THE L-070 PROJECT

\subsection{ADMINISTRATION AND ANTHORITY}

\subsection{TEST ENGINE:?}

The WHC ATP Test Engineer is responsible for directing performance of the ATP and for personnel and plant safety as related to the perfoimance of the ATP. The Test Engineer irects contractor aiv' WHC personnel assigned to the ATP. is Test Engineer is at thorized to make field changes to the AT!

3.2 TEST

WHC ario ciscoractor personnel assigned ATP related tasks are directly resiunsible for ATP performance and plant and personnel "iety. Test performers report to the Test Engineer.

3.3 TAGOUTS

ICF Kaiser Hanford Company or its constill tion subcontractor shall be responsibi: $\hat{\text { rol }}$ lock-and-tags a $: \therefore i l$ designate a tag custodian during AT: ,erformance.

3.4 CHANGES

ATP changes required during testing may be made i,intaiately in the field copy, provided iiat the changes canlici iffect operating facility safety, fuil $+j i_{i}$, or performancs and will not compromise or influence test $i=t$. Any such change must be recorded in the change $\log$ as ? rinange exception.

ATP changes that affect operating facilitis safety, function, or performance or will compromise or 10 iluence test data are made via an ECN to the ATP Supporting Document (SD).

\subsection{TEST FAILURE}

All steps in the ATP involving equipment operation or data verification must pass their acceptance criteria. Failures must be corrected and retested, or dispositioned with test engineer approval. The test engineer will decide whether to continue with the ATP in the event ATP steps fail. 
WHC-SD-L070-ATR-001, REV. 0

ACCEPTANCE TEST REPORT FOR THE

L-070 PROJECT

3.6 TEST LOG

A $\log$ of changes or exceptions (appendix B) to testing activities is to be maintained by the test engineer.

\subsection{EXCEPTIONS}

The ATP may not be closed with open exceptions. All exceptions shall be recorded in appendix $B$, unless they are immediately correctable and retested. Prior to the close of the ATP each exception is dispositioned. When all exceptions are dispositioned then the ATP may be closed.

3.8 EXCEPTION DISPOSITION

Dispositioning of exceptions usually takes one of four forms as shown below. This does not prevent other means of dispositioning if agreed upon by WHC.

a. The contractor corrects the exception.

b. WHC accepts the exception as is.

c. The exception is transferred, to the project managers open item 1 ist.

d. The exception is handled using a combination of a. through $c$. above.

Exceptions are closed when they have been dispositioned and signed by the Test Engineer.

\subsection{SIGNATURES}

Persons signing for performance steps certify that they have personaliy witnessed or performed the step (s) or that they have received a direct report of completion from test personnel. 
WHC-SD-L070-ATR-001, REV. 0

ACCEPTANCE TEST REPORT FOR THE L-070 PROJECT

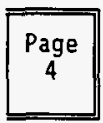

\subsection{PREREQUISITES}

All of the following prerequisites must be completed before any testing is performed in the ATP. Other prerequisites must be completed in each major section and are identified as "Special Prerequisites".

4.1 The contractor certifies that all process equipment and controls associated with the ATP are ready for testing to commence. Exceptions will be noted in the test log and will

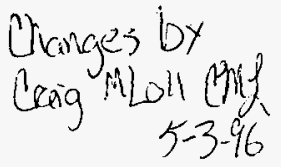
have the concurrence of the Test Engineer.

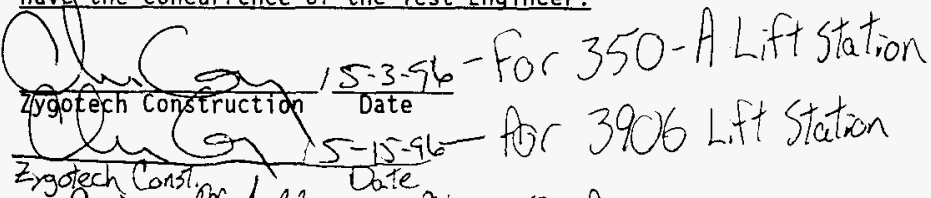
Covir ong fold $\frac{5-3-96}{\text { Date }} 350$ - A

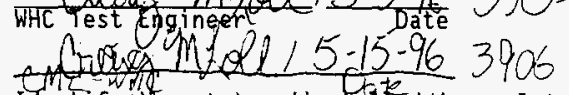

4.2 Identify the status (instated/incomplete) of the 350-A Lift Station. If the lift station has been installed, then it will be tested per this ATP. If the 350-A Lift Station has not been completely installed, Section 8.0 of this ATP does not have to be completed.

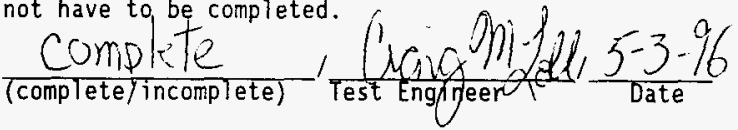

4.3 All danger and caution tags have been removed from equipment that will be tested or existing tagouts have been discussed with the contractor and their impact on the ATP is acceptable to proceed with testing.

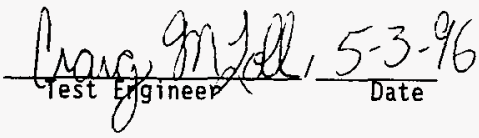


WHC-SD-L070-ATR-001, REV. 0

ACCEPTANCE TEST REPORT FOR THE

L-070 PROJECT

4.4 A pre-job safety meeting has been held and all personnel involved in the ATP have signed off on the pre-job +oster:

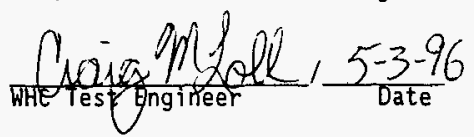

4.5 When all prerequisites are completed then sign below to formaliy authorize the commencement of testing activities.

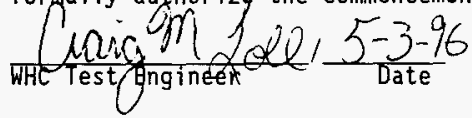

5.0 GENERAL INSTRUCTIONS

This section provides general requirements that apply during the entire ATP performance. The test engineer and contractor test performers must read this section prior to performing any ATP testing.

\section{Instructions}

5.1 An exception will be logged (Appendix B) for any step not meeting the requirements of the ATP unless the exception can be corrected and retested during the present shift.

5.2 Each major section $(X .0)$ is performed sequentially. The Test Engineer has authority to perform major sections out of sequence (without an ATP change) provided:

1. The "Special Prerequisites" in that section are completed.

2. Performing the section out of sequence will not adversely impact any unfinished (previcus or subsequent) sections or adversely impact the ATP performance schedule.

5.3 The Test Engineer signoff of test steps certify that direct observation or inspection has been made or that a report was recieved from test personnel signifying that the step was performed. 
WHC-SD-L070-ATR-001, REV. 0

ACCEPTANCE TEST REPORT FOR THE L-070 PROJECT

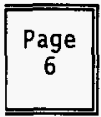

5.4 LEAD/LAG ... The lift station pumps are controlled by a LEAD/LAG scheme that controls which piece of equipment will start next. When a piece of equipment shutsdown then its status should change to LAG. When equipment with a $L E A D$ status is taken out of AUTO then a LEAD status should bereassigned to the other piece of equipment if it is in AUTO.

\subsection{LIFT STATION 3906 PUMP (LSP-I,2) TESTING}

This section tests the sump pumps for proper operation. After this test is completed the sump controls may be left in automatic.

\section{Special Prerequisites}

6.1

Notify 310 Facility (373-5082) and 340 Facility (376-3420) personnel that testing will be performed on $3906 \mathrm{Lift}$ Station and that they will receive an alarm signal.

6.2 When all prerequjsites are completed then sign below.

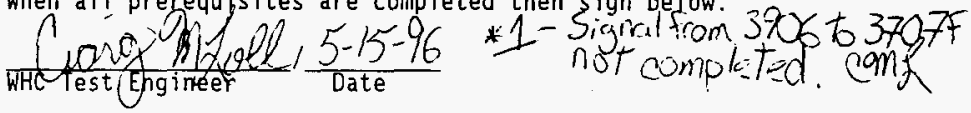

\section{Instructions}
6.3 Ensure electrical suppiy breakers are open for both sump pumps.

6.4 Bump test each pump as follows:

6.4.1 Position the HAND/OFF/AUTO switch for the pump to OFF.

6.4.2 Verify no obstructions are present that would hinder equipment operation.

6.4.3 Close the electrical supply breaker.

6.4.4 Position the HAND/OFF/AUTO switch for the pump to HAND and run the equipment for ${ }^{-5}$ secs. then position to OFF.

6.4.5 Verify the equipment is stopped. 
WHC-SD-L.070-ATR-001, REV. 0

ACCEPTANCE TEST REPORT FOR THE

L-070 PROJECT

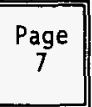

6.5 Start filling sump with water.

6.6 Turn HAND/OFF/AUTO switches for both pumps to AUTO.

6.7 Verify that LSP-1 (LSP-2) pump starts as water rises approximately 2.25 feet from the bottom of the sump.

6.8 Verify that flow registers on FIT-3906, the local readout $* 2$ for the 3906 Lift Station discharge. $(0-260 \mathrm{gpm})$

6.9 Pumpthe sump down to the bu level shitoff (cpproximatel, I foot)

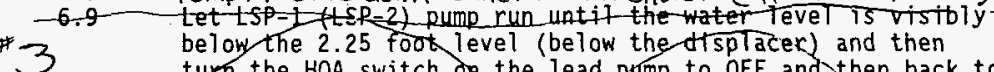

tyrn the HOA switch on the lead pump to OFF and then back to
CAUTO. (This should change- the Tead/lag status of the-pumps)

6.10 Fill the sump to the lead pump on level again (approximately

- 2.25 feet of water).

6.11 Verify that LSP-2 (L.SP-1), previously in the lag position now starts up.

6.12 Turn both pump HOA switches to OFF.

6.13 Fill the sump to approximately 4.25 feet.

6.14 Verify that the local colored alarm light comes on.

6.15 Verify that the "High" level alarm signal is received at the 310 Building control room (phone: 373-5082) or one of the computer panels (3707F or 340 Control Room) at the 340 Facility (phone:376-3420).

6.16 Position both the pump HAND/OFF/AUTO switches to AUTO

6.17 Verify that both pumps start and run.

6.18 Verify that both pumps shut off at approximately 1 foot of water. 
WHC-SD-L070-ATR-001, REV. 0

ACCEPTANCE TEST REPORT FOR THE

L-070 PROJECT

6.19 Record the status (auto/secured) of the sump system below.

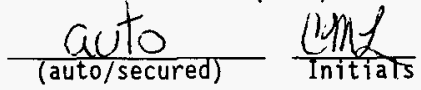

6.20 When testing in this section is completed then sign below.

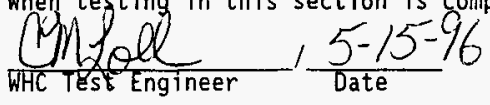

\subsection{MANHOLE PS-72 SIGNAL}

This section provides Verification that the flow signal from the PS72 ISCO Flowmeter is being received on the Waste collection Sump screen on CP-1, at the 310 Building.

\section{Special Prerequisites}

7.1 Signal wires have been connected per ICF Kaiser Hanford Co. Orawing $\mathrm{H}-3-304724$, sheet 1 of 1 , rev. 0 .

7.2 When all prorequjsites are completed then sign below.

\section{Instructions}

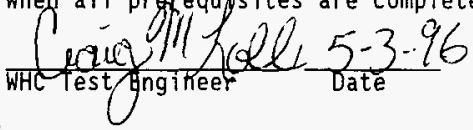

7.3 Verify that a flowrate for the PS-72 flowmeter is being displayed on the $C P-1$ computer screen at the 310 Facility control room. (Phone: 373-5082)

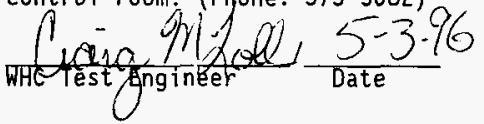


WHC-SD-L070-ATR-001, REV. 0

ACCEPTANCE TEST REPORT FOR THE L-070 PROJECT

\subsection{LIFT STATION 350-A PUMP (LSP-1,2) TESTING}

If prerequisite 4.2 has been signed off as INSTALLED, perform this section. If it has been signed off as INCOMPLETE, N/A steps 8.1 , 8.16 and $\operatorname{sign} 8.17$.

This section tests the sump pumps for proper operation. After this test is completed the sump controls will be left in the "OFF," position.

\section{Special Prerequisites}

8.1 When all prerequisites are completed then sign below.

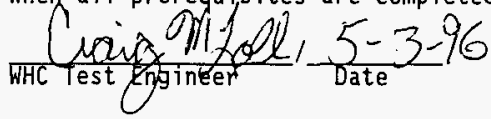

Instructions

8.2 Verify electrical supply breakers are open for both sump pumps.

8.3 Bump test each pump as follows:

8.3.1 Position the HAND/OFF/AUTO switch to OFF.

8.3.2 Verify no obstructions are present that would hinder equipment operation.

8.3.3 Close the electrical supply breaker.

8.3.4 POsition the HAND/OFF/AUTO switch to HAND and run the equipment for -5 secs. then position to $O F F$.

8.3.5 When bump testing is completed verify the equipment is stopped.

8.4 Start filling sump with water.

8.5 Turn HAND/OFF/AUTO switches for both pumps to AUTO.

8.6 Verify that LSP-1 (LSP-2) starts as water reaches the "lead pump on," level (approximately 2.5 feet). 
8.7 Pumpthe sump down to the low level shitoff (approximately / foot)

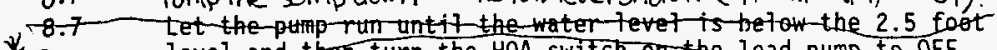
* 3 level and then turn the HOA switch on the lead pump to OFF

C status of the pumps)

8.8 Fill the sump to the "lead pump on" level again.

8.9 Verify that LSP-2 (LSP-1), previously in the lag position, starts up.

8.10 Turn both pump HOA switches to OFF.

8.11 Fill the sump to the "alarm," level, which is approximately three inches below the horizontal section of the discharge piping from the sump pumps.

8.12 Verify that the local colored alarm light comes on.

8.13 Position both the pump HAND/OFF/AUTO switches to AUTO

8.14 Verify that both pumps start and run.

8.15 Verify that both pumps shut off at approximately 6 inches above the bottom of the sump.

8.16 Position both the pump HAND/OFF/AUTO switches to OFF.

8.17 Position the electrical supply breakers to the "OPEN," position.

8.18 When testing in this section is completed then sign below.

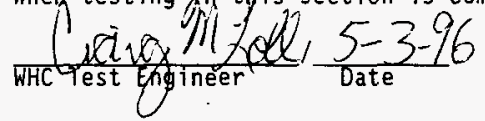


WHC-SD-L070-ATR-001, REV. 0

ACCEPTANCE TEST REPORT FOR THE

L-070 PROJECT

\section{Appendix A: Instructions for completing Exceptions Log}

\section{Instructions}

1. If the proposed change affects personnel safety then change the ATP JSA instead of changing the ATP.

2. If the change affects equipment function or performance or compromises or influences test data then an ECN must be issued prior to making a change.

3. If the change does not effect function or performance or compromises or influences test data or if an ECN has been approved then the ATP change is performed per the following instructions using the ATP change form on the next page.

i:

A. Enter the next sequential exception lchange serial number in appendix $B$.

B. Enter a detailed description of the exceptionlchange including section, page etc. or the change may be attached to the form that shows the "as is" conditions and the "should be" conditions.

D. Enter the change in the ATP. New typewritten pages may be substituted for pages that do not contain data or signatures. Pages being replaced that contain data or signatures must be saved in appendix $P$. The ATP change number, date and initials of the person making the change must appear on each page or in the vicinity of the change.

E. Sign the ATP exception/change form indicating the change has been made and insert the form in appendix $F$. 
WHC-SD-L070-ATR-00t, REV. 0

ACCEPTANCE TEST REPORT FOR THE

L-070 PROJECT

\section{Appendix B: ATP EXCEPTIONS/CHANGES}

\section{EXCEPTION/CHANGE LOG}

Instructions: Enter the next sequential serial number i.e 001 and a short description of the item. Fill out the exception form using the serial number obtained from this log.

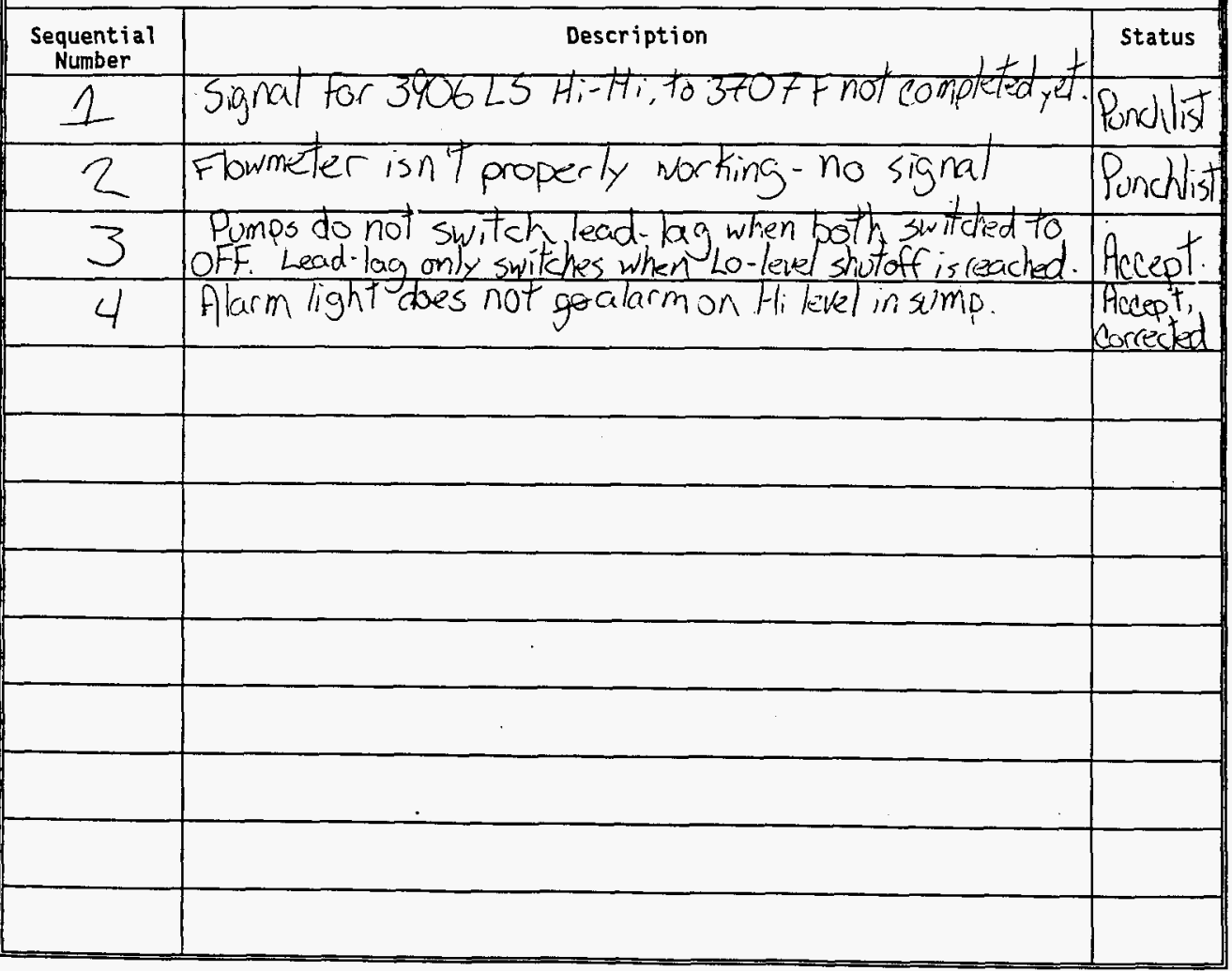


JOB SAFETY ANALYSIS

\section{:No. $\angle-070$

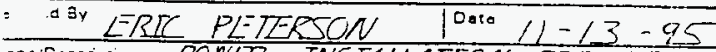 \\ Wark CreserNo.

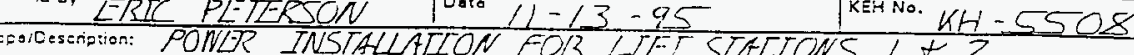

Pago 1 of 2

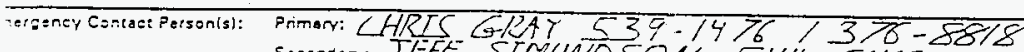

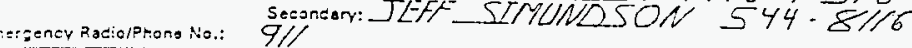

entic Work Lesation(s): $\triangle I F T$ STATIONS $7 \mathrm{~T}$.

KNOVVN OR POTENTAL HAZARDS

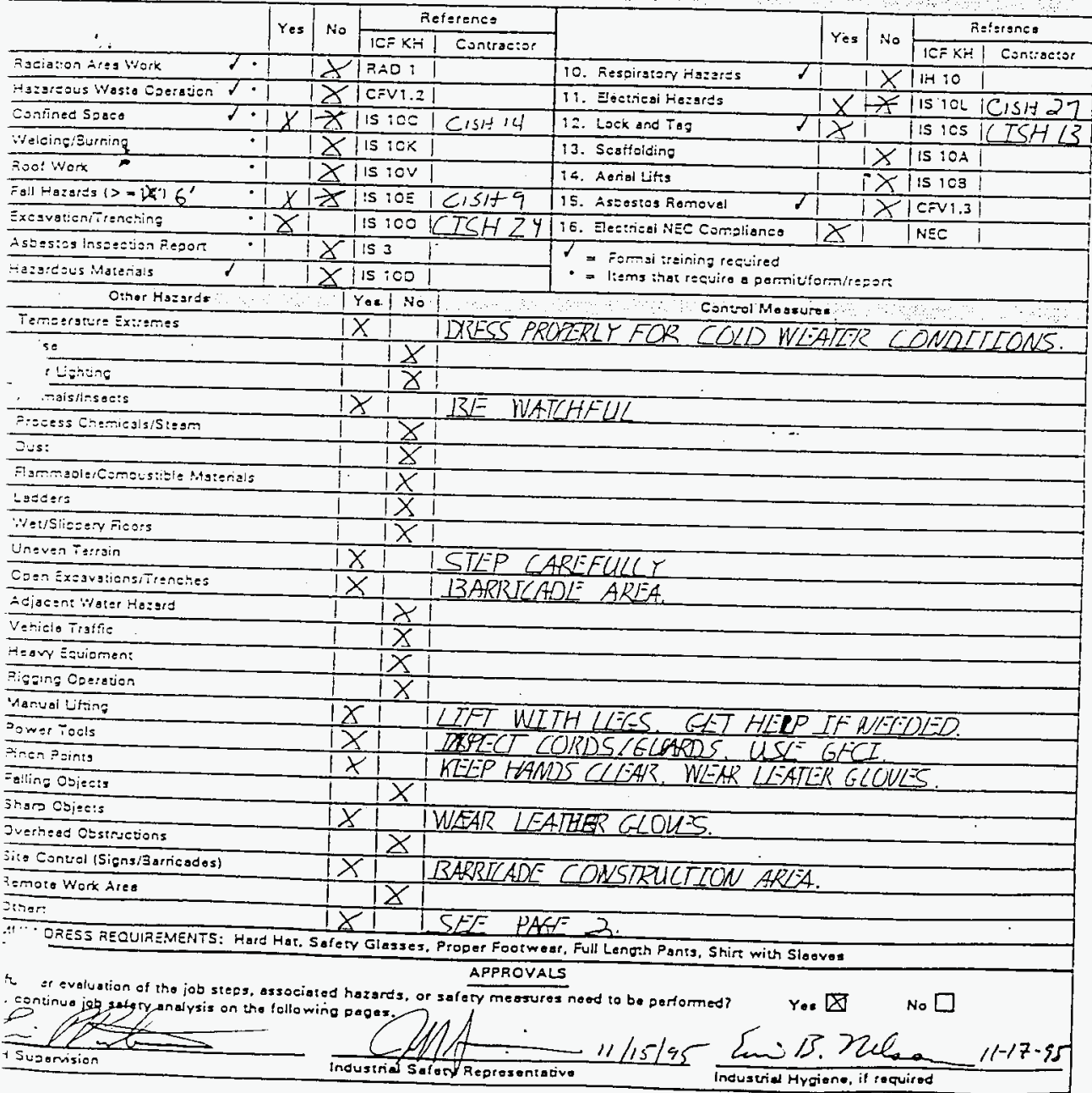




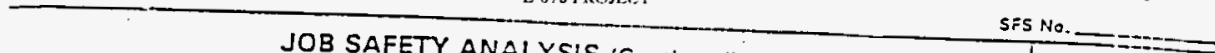

$\angle C C K+T A G$ YECTRICAL TIL: INS.

SHOCK I INUUURY

OWER TOOLS

TNTURIES.

SEENERAL WORK.

INTURTES.

GENETR

ONDUIT INSTALATION

ROTORHAMMER TO. INSTALL DROP.IN
THIURIES.

Fale Itrazans over $6^{\prime}$ in lfEight

CONFIULS SPACE

(LIFT STATIUN mantialES)

SILICA DUST
RECUIRED SAFETY MEASURESIPPE

FOLIOW CISH LB

USE ONLY WITH GIECT

INSPECT DAILY.

COROS TO HAVL GROUND RINS.

GLAROS TO RLE IN PLACE.

WLAR P.P. E.

HARO HATS. STLEZ - TOLD
BOOLS.

SAOETY GLASSES.

HAVE CURRIENT MSOS FOR PUC GLUE. GLUE IN WLEUL VENTILATED ARLA.

SEE FAL protentien WURIC PIAT

SEE CONFIULSOS SArTé EUTHY PEAMT.

USE WET METHUD 


\begin{tabular}{l|l|l|l|}
\hline Projac: No. $\angle-070$ & Work Order No & Area 300 & Bidg. 3SOA A \\
\hline Prepared BY MLES TAKAK, & Date 3/25/96 & KEH No. 5508 & \\
\hline
\end{tabular}

Scope/Description: ELECTRICAL INSTALLATION

Emergency Contact Person(s) Primary: CHRIS GRAY $539-1476$

Secondary: JefF simunoson $544-8116$

Emergency Radio/Phone No.: 911

Specific Work Locations(s): LIFTSTATION NO.1@ @A+NT SHToP 350A BLDG

KFOWH OR POTENTIAL HAZABDS

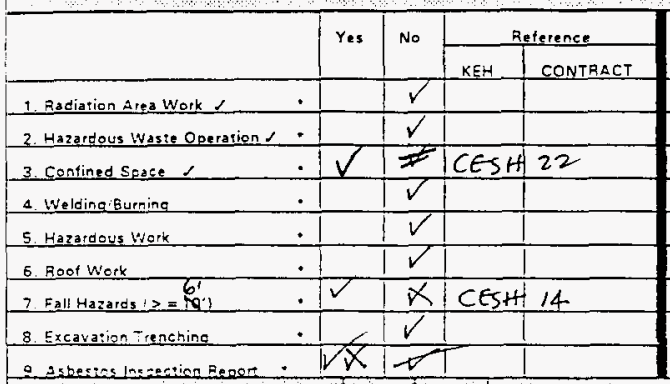

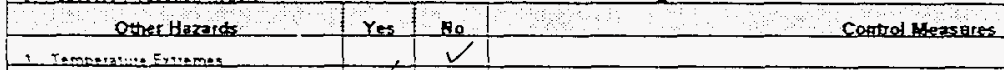

\begin{tabular}{|l|l|l|l|}
\hline Naise & $\checkmark$ & & USE HEARING PROTECTION AS LEQUIRED \\
\hline 3 Dorrighing & & $\checkmark$ &
\end{tabular}

3 Porrlizhing.

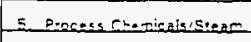

E. Di...

7 Elampabie Comuscible Marevials

\& Lacders

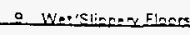

10 Uneven Terrain

11. Ozen Eurzuatizos, Trenches

12. Adacen: Water Hazard

12 Vehiche $T_{r_{2}}{ }^{4}+{ }_{1 C}$

14 Heayy Exuiamen:

15 . Eigoina Oceration

15. Manuall itito

17 Dower Toels

is Pinch Point:

10 Fallice obients

20 Shaw Objects

2) Overthead obsumctions

22 Site Convol Sjons/Barticades 1

23 lamore Wark A.res

24 one:

10. Hazardous Materiais ,

19. Respinatory Hazards

12. Elecitical Hazards.

13 Lock and Tag,

i4. Scaffolding.

15. Aerial Lits,

16. Asbestos Remeval

$f=E_{e t m a l}$ training required

- liems that

\begin{tabular}{|c|c|c|c|}
\hline \multirow[t]{2}{*}{ Yes } & \multirow[t]{2}{*}{ No } & \multicolumn{2}{|r|}{ Refetence } \\
\hline & & KEH & CONTRACTOR \\
\hline & $\checkmark$ & & \\
\hline & $\vec{V}$ & & \\
\hline$\sqrt{ }$ & & CESH & $23 A \& 236$ \\
\hline$\checkmark$ & & Cest & 24 \\
\hline & $\checkmark$ & & \\
\hline & $\checkmark$ & & \\
\hline & $\checkmark$ & & \\
\hline
\end{tabular}

CESH $23 A \& 23 B$

$\checkmark$ BE AWHAE IARSTADKIT AVACAOLE

\begin{tabular}{|l|l|l|}
\hline$\checkmark$ & & \\
\hline & $\checkmark$ &
\end{tabular}

\begin{tabular}{|l|l|l|l|l|l|} 
& $\checkmark$ & $\checkmark$ & \\
\hline & $\checkmark$ & $\checkmark$ & \\
\hline
\end{tabular}

$\checkmark|⿰|$ SECURE PROPER FOTING FOK STEP LADDERS/SETIINAC LADOERS

MINIMUM DRESS RECUIREMENTS: Hatd Hat. Satety Glasses, Proper Footweat, Full Length Pants, Shin with Sle eves

Apppovals
Does furgherevityation of the job steps.associated hazards, or safety measures need to be pertarmed?




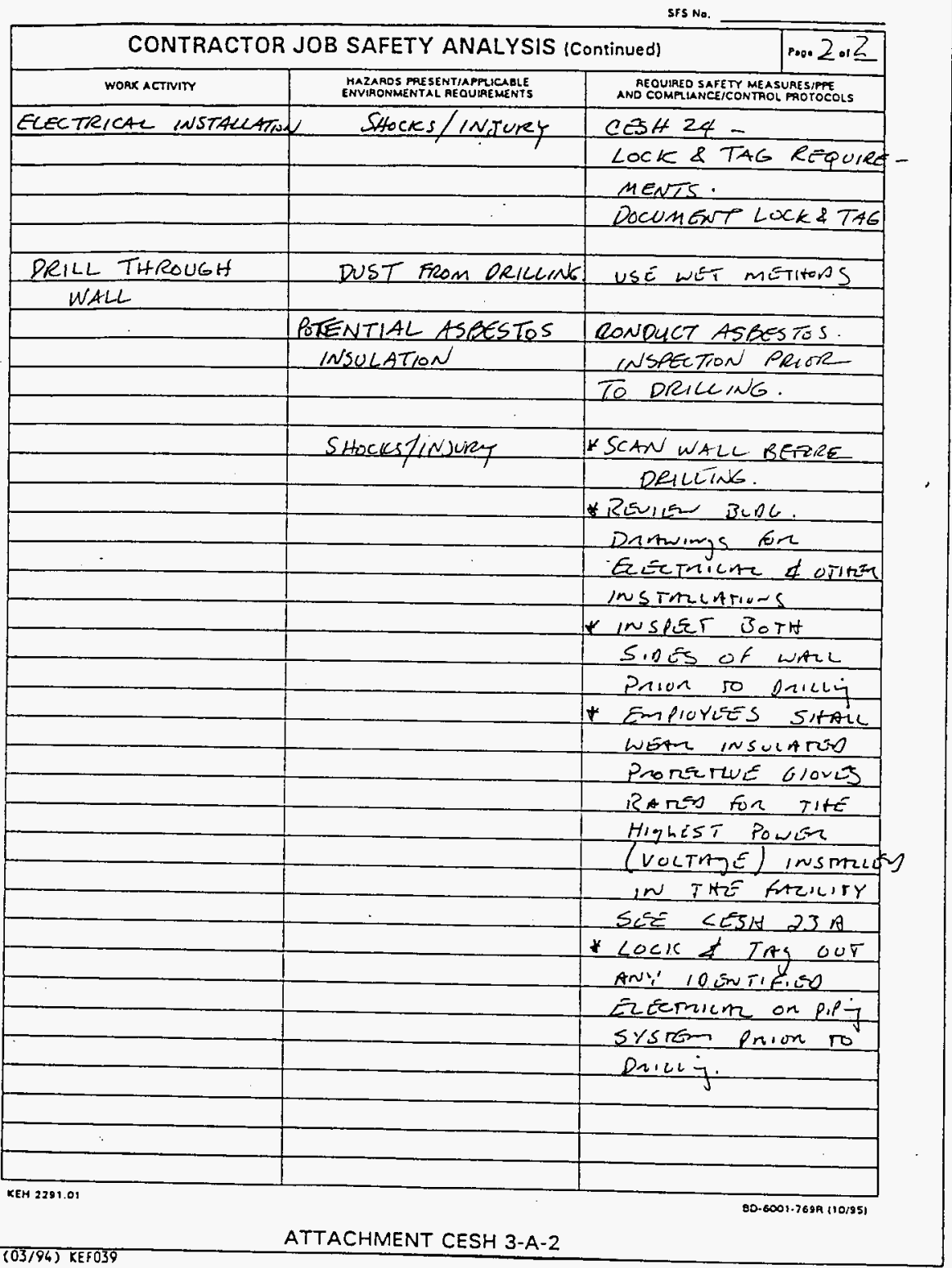


WHC-SD-L070-ATR-001, REV.0

\section{PREJOB SAFETY PLANNING SIGNOFF}

I have read the atrectied Projob Plan, Hezardous Work Pormit and/or JSA and underatand the hazerds aesociared with enie job.

sob Number $K$ if 5508

\begin{tabular}{|l|l|l}
\hline Date & Payrall No. & Name (Print)
\end{tabular}

Jab Loeation LIFTSTATION

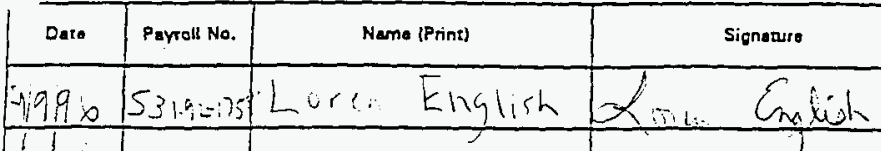

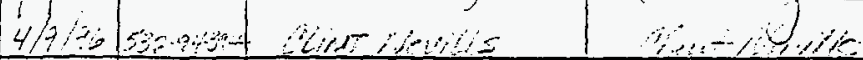

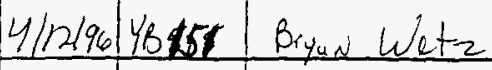

14/12/ac 536-52-424/ Jason C. Wilson

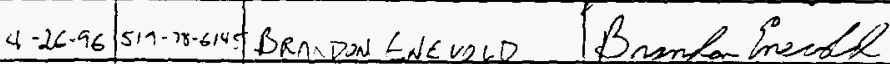

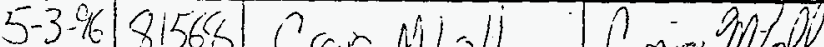

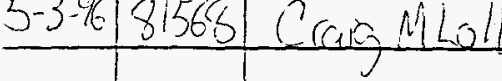

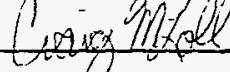

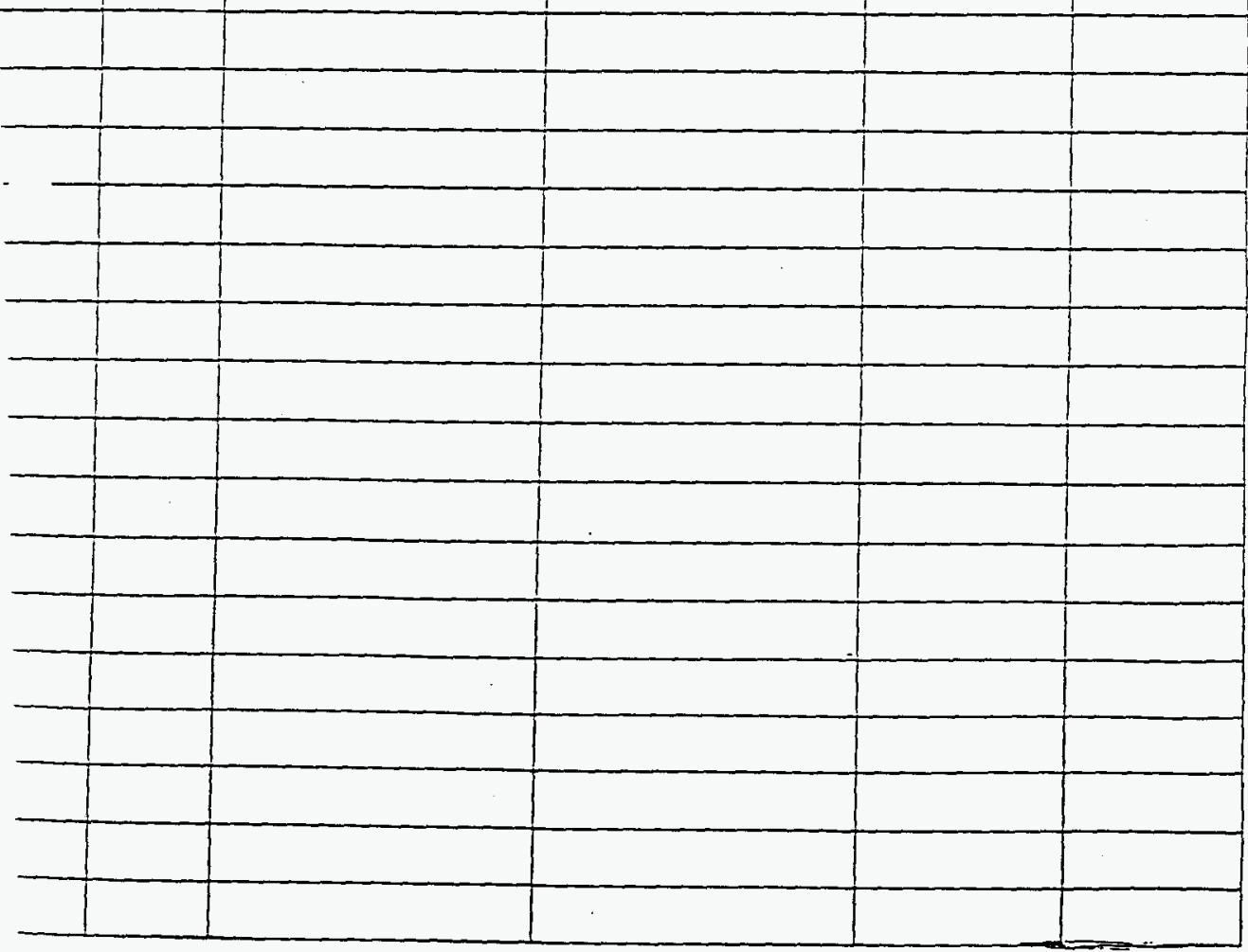

